\title{
Usage of Porcelain Insulators Wastes in the Preparation of Cement Based Building Units
}

\author{
N. F. Abdel Salam
}

\begin{abstract}
Porcelain electrical insulators manufactured from refractory ceramic materials have to pass stringent tests prior to final acceptance. This causes large amounts of wastes to be available at the plant premises representing a waste of material besides being an environmental threat. In the present work, porcelain wastes were crushed and ground to pass 40 mesh screen and used as partial sand replacement in cement mortar cubes as first step for possible use in concrete works. The effect of particle size and percent addition on water of consistency and setting time of cement paste and flow behavior of mortars and their compressive strength was investigated. The results showed that the substitution of sand by the waste moderately altered most of the properties but helped raising the mechanical strength.
\end{abstract}

Keywords: Electrical porcelain - waste - cement - mortar.

\section{INTRODUCTION}

$\mathrm{T}_{\mathrm{r}}$ he manufacture of high voltage porcelain insulators goes through several stages. It starts with selecting proper raw materials, namely kaolin, ball clay, quartz and feldspar [1, 2]. After proper crushing and grinding, they are mixed with water and shaped using either extrusion or pressing [1]. Next, their external surface is finned using a jiggering machine. The shaped products are than dried and fired to temperatures exceeding $1200^{\circ} \mathrm{C}$ to develop a liquid glassy phase that will decrease the porosity on cooling usually to less than $10 \%$. The produced elements are then tested for mechanical strength, breakdown voltage and dielectric properties [3]. Because of the stringent standards, an appreciable proportion of the daily production has to be discarded usually as shanks of 20 to $400 \mathrm{~mm}$ size. This represents an economic burden on the factory since their manufacture is an energy consuming process, besides having to transport this waste into special dump fill areas.

The aim of this work is to use this waste to substitute sand in cement mortars as a preliminary step for using it as both fine and coarse aggregate in concrete works. In this connection, the replacement of sand by waste materials in cement mortars or concrete has been tackled by many researchers. De Oleiveira et al [4] investigated the possibility of using finely ground waste glass as partial replacement for sand in concrete. They reported an increase in 28 days compressive

Revised Manuscript Received on December 30, 2019.

* Correspondence Author

N. F. Abdel Salam*, faculty, Department of Chemical Engineering, Cairo University, Giza, Egypt. E-mail: nourafathy_1983@cu.edu.eg

(C) The Authors. Published by Blue Eyes Intelligence Engineering and Sciences Publication (BEIESP). This is an open access article under the CC BY-NC-ND license (http://creativecommons.org/licenses/by-nc-nd/4.0/) strength from $46 \mathrm{MPa}$ to $58 \mathrm{MPa}$ following 25\% substitution, after which no appreciable increase in strength was noticed. They did not however include in their work the effect on slump. A similar approach was adopted by Mageswari et al [5] who used sheet glass powder to replace sand. The best concrete properties were obtained at 10 to $20 \%$ substitution levels. Also, Keerthinarayana et al [5] researched substituting sand by crushed spent fire bricks. They found out that at low replacement levels, the compressive, split tensile and flexural strength decreased to increase once more at higher levels reaching a maximum at about $20 \%$ in all cases. Fly ash also used to partially replace sand by more than one author [6, 7]. In general it was found that the presence of fly ash sets in a pozzolanic reaction that highly raises the compressive strength. The replacement level is however limited by the extremely fine size of ash compared to sand. On the other hand, Reddy [8] investigated the replacement of sand by fine stone dust and ceramic waste and found out that the incorporation of stone dust increased the strength up to $20 \%$ level. However any inclusion of the ceramic waste in the mix led to diminishing that effect. Aluminum waste was used by Rahim et al [10] as sand replacement. The maximum strength was obtained at $1 \%$ replacement while the lowest water absorption was at 5\% level. In an attempt to use agricultural waste as sand replacement, Prusty et al [11] used a mixture of such wastes and concluded that agro-waste concrete containing bagasse ash, sawdust ash and oyster shell achieved the required strength by $20 \%$ of replacement as fine aggregate. Using PET plastic, Thorneycroft et al [12] reached a compressive strength of $54 \mathrm{MPa}$ by substituting $10 \%$ sand by volume by the plastic material. A different approach was used by Bendary et al [13] by substituting sand by the waste from alum production in cement mortars.. They tested the fluidity of mortar, the initial and final setting times and the 28 days compressive strength and concluded that a $7.5 \%$ waste level increased the compressive strength over the control sample by $10.7 \%$. Following the same line, Moselhy [14] used the same waste as sand substitution in concrete whereby he found out that while the slump decreased linearly with waste addition, the 28 days strength reached a maximum value at $7 \%$ substitution.

In the present work, the replacement of sand by ground electric porcelain waste in cement mortars is tried as first step in subsequent application to concrete mixes. Next, possible replacement of cement was also tried. 


\section{MATERIALS}

\section{A. Porcelain waste}

Porcelain waste was finely ground to pass 28 mesh sieve $(589 \mu \mathrm{m})$ in a laboratory ball mill after being hand crushed. Its particle size distribution was assessed by a set of standard sieves according to ASTM D 422-63 [15].

The distribution is shown in Fig.1. The median particle size $\mathrm{D}_{50}=280 \mu \mathrm{m}$.

\section{B. Sand}

Natural sand composed of $98.8 \%$ silica as per XRD analysis was screened and the screen analysis also shown in Fig. 1. Its median particle size $=420 \mu \mathrm{m}$.

\section{Water}

Normal tap water was used in all experiments.

\section{Cement}

Normal Portland cement grade 42.5 was used in all experiments.

\section{EXPERIMENTAL WORK}

\section{A. Chemical analysis}

Chemical analysis of the raw materials was carried out using X-ray fluorescence (XRF) to determine the chemical composition of the materials using Axios, Panalytical 2005, WD-XRF spectrometer. The analyses of the fine waste is shown in Table I. That of sand was reported as it consisted of $98.8 \% \mathrm{SiO}_{2}$.

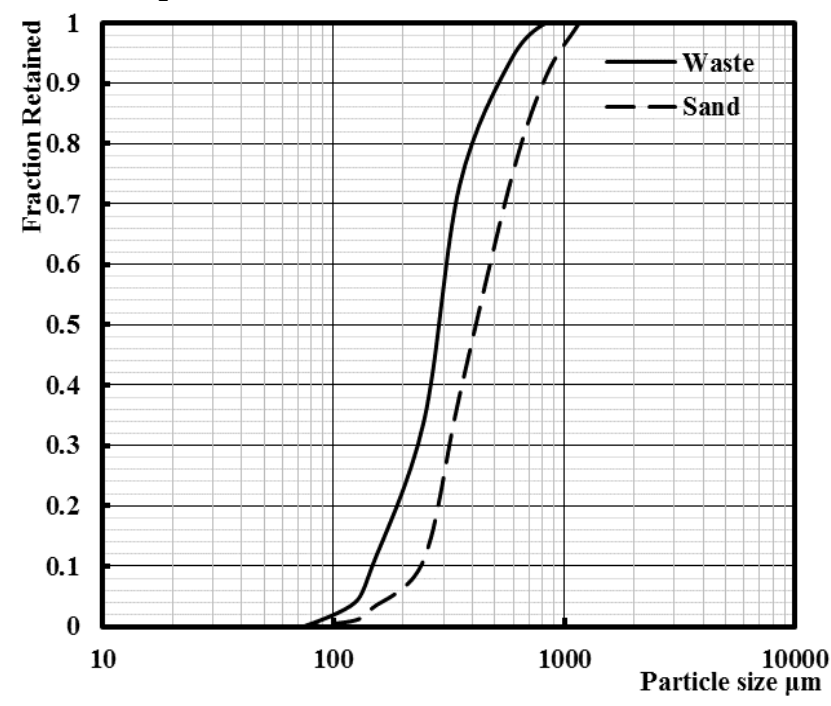

Fig.1. Particle size distribution of sand and waste

Table-I: The analysis of the fine waste

\begin{tabular}{|c|c|c|c|c|c|c|c|c|}
\hline $\begin{array}{c}\text { Oxid } \\
\text { e }\end{array}$ & $\begin{array}{c}\mathrm{Si} \\
\mathrm{O}_{2}\end{array}$ & $\begin{array}{c}\mathrm{Al}_{2} \\
\mathrm{O}_{3}\end{array}$ & $\begin{array}{c}\mathrm{TiO} \\
2\end{array}$ & $\begin{array}{c}\mathrm{Ca} \\
\mathrm{O}\end{array}$ & $\begin{array}{c}\mathrm{Mg} \\
\mathrm{O}\end{array}$ & $\begin{array}{c}\mathrm{Fe}_{2} \mathrm{O} \\
3\end{array}$ & $\begin{array}{c}\mathrm{Na}_{2} \\
\mathrm{O}\end{array}$ & $\begin{array}{c}\mathrm{K}_{2} \\
\mathrm{O}\end{array}$ \\
\hline $\begin{array}{c}\text { \% } \\
\text { by } \\
\text { Wei } \\
\text { ght }\end{array}$ & 55. & 39.7 & 2.1 & 0.3 & 0.1 & 1.55 & 0.1 & 0.2 \\
8 & & 4 & 5 & & 2 & 1 \\
\hline
\end{tabular}

The phases constituting the waste were assessed using XRD analysis by means of a mono-chromatized Copper $\mathrm{K} \alpha$ radiation which operate at $40 \mathrm{~mA}$ and $40 \mathrm{kV}$. Philips diffractometer type (PW 1730). The pattern revealed the presence of three phases: Mullite $\left(3 \mathrm{Al}_{2} \mathrm{O}_{3} \cdot 2 \mathrm{SiO}_{2}\right)$, rutile $\left(\mathrm{TiO}_{2}\right)$ and quartz. Other phases relating to the presence of minor oxides were not detected presumably because of their weight percent being lower than $2 \%$, the normal limit of detection by XRD [16].

\section{Determination of powder densities}

The densities of the three raw materials used in the present study were determined by the density bottle method following ASTM D854 - 14 [17]. The values were as follows: cement $=3.08 \mathrm{~g} \cdot \mathrm{cm}^{-3}$, sand $=2.66 \mathrm{~g} \cdot \mathrm{cm}^{-3}$ and porcelain waste $=2.78 \mathrm{~g} . \mathrm{cm}^{-3}$.

\section{Preparation of specimens}

A mechanical mixer (Kenwood) of 2 liters capacity and adjustable rotating speeds was used to prepare pastes and mortar for 2" molds. Mixes were homogenized in 5 minutes mixing time. First the solid materials were dry mixed for one minute and whilst the blade was rotating water was added.

\section{E. Determination of water of consistency and setting time}

The water of consistency of cement paste was determined using the Vicat needle apparatus in accordance with ASTM C187 - 16 [18]. The initial and final times of setting were determined according to ASTM C191-19 [19].

\section{F. Flow behavior of mortars}

Flow characteristics for each mortar were measured in accordance to ASTM C 1437-15 [20] by the flow table test. Specifications for the flow table and truncated flow cone are found in ASTM C230 / C230M - 14 [21]. This test essentially relies on placing the mortar on a rotating table and measuring the relative increase in its diameter.

\section{G. Curing}

Mortar samples were stored in a tank partially filled with water and covered with a lid to provide a curing condition of the measured humidity and temperature. In the current experimental program curing of the casted cubes was performed for 2, 7 and 28 days.

\section{H. Compressive strength}

This was measured after 3, 7 and 28 days curing. Each sample consisted of three 2" cube specimens. The average value of strength was calculated each time. The compression test was performed and results obtained according to ASTM C109/C109M-16 [22]. 


\section{RESULTS AND DISCUSSION}

\section{A. Composition of mixes}

Eight mixes were prepared with the fine waste powder substituting sand at a fixed mass of cement. Table II shows the composition of these mixes.

The percent waste refers to the percentage of waste with respect to cement.

Table-II: Composition of cement mortar (by weight)

\begin{tabular}{|c|c|c|c|c|c|}
\hline $\begin{array}{c}\text { \% } \\
\text { Waste }\end{array}$ & $\begin{array}{c}\text { Waste } \\
(\mathbf{g})\end{array}$ & $\begin{array}{c}\text { Sand } \\
(\mathbf{g})\end{array}$ & Waste/Sand & $\begin{array}{c}\text { OPC } \\
\text { (g) }\end{array}$ & $\begin{array}{c}\text { Water } \\
(\mathbf{g})\end{array}$ \\
\hline 0 & 0 & 275 & 0 & 170 & 110.5 \\
\hline 5.88 & 10 & 265 & 0.0377 & 170 & 110.5 \\
\hline 11.76 & 20 & 255 & 0.0784 & 170 & 110.5 \\
\hline 17.65 & 30 & 245 & 0.1225 & 170 & 110.5 \\
\hline 23.53 & 40 & 235 & 0.1702 & 170 & 110.5 \\
\hline 29.41 & 50 & 225 & 0.2222 & 170 & 110.5 \\
\hline 35.29 & 60 & 215 & 0.2791 & 170 & 110.5 \\
\hline 41.18 & 70 & 205 & 0.3414 & 170 & 110.5 \\
\hline
\end{tabular}

\section{B. Effect of waste addition to cement paste on water of} consistency

Waste was added in the proportions shown in Table II to plain cement and hand mixed for 5 minutes. Water was gradually added and water of consistency determined as function of percent waste (with respect to cement). The relation is shown in Fig. 2 which reveals that the water of consistency increases with added waste. This phenomenon has been previously noticed by Lawrence et al [23] when adding several types of inert materials to cement and was interpreted as enhanced heterogeneous nucleation of hydrates. In the present case, the added fine contains free silica (as proved by XRD analysis) and hence increases this effect by random nucleation of calcium silicates through its pozzolanic reaction with calcium hydroxide formed in cement paste.

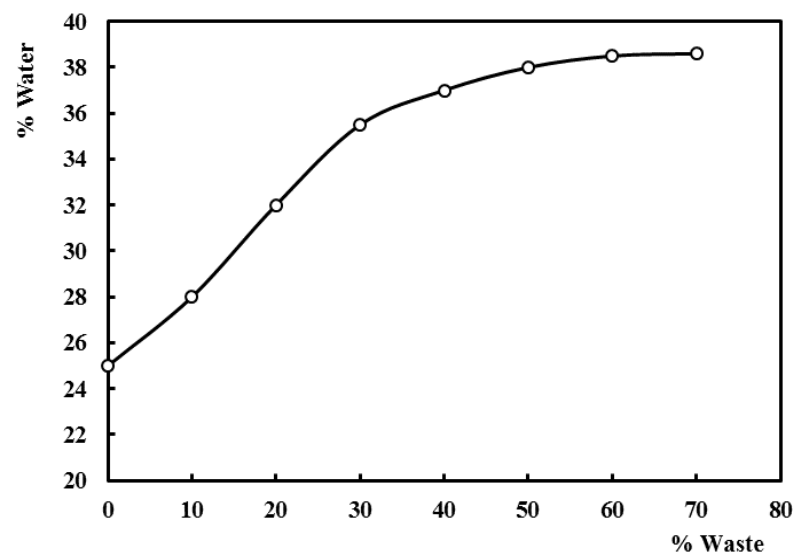

Fig.2. Effect of waste addition on water of consistency of cement paste

\section{Effect of waste addition to cement paste on setting time}

The effect of waste addition on the setting times (initial and final) of cement paste was to reduce the time required for setting, presumably because of the mild pozzolanic reaction taking place thereof as shown if Fig. 3. A similar effect was observed by Thongsanitgarn et al [24] on incorporating fine limestone in the cement paste.

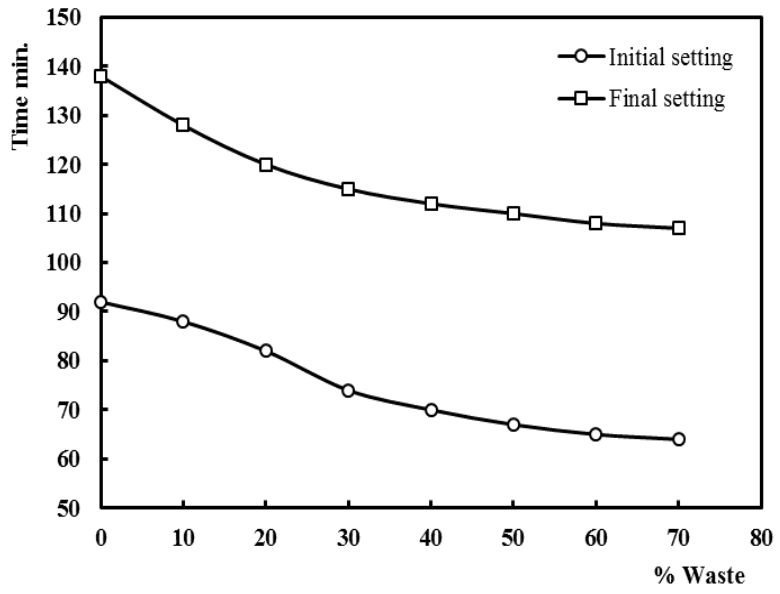

Fig.3. Effect of waste addition on water of consistency of setting time

\section{Effect of waste replacement for sand on flow properties of mortar}

To assess the effect of substituting sand by the porcelain waste, the recipes shown in Table III were tested by the flow table. The results are shown in Fig. 4 for flowability as expressed by the ratio between final and initial diameter of spread mortar (as percent).

As can be seen from that figure, it is evident that replacing sand by the finer waste powder has resulted in a decrease in flow index of the mortar. The percent "flowability" decreased from $108 \%$ to reach an almost asymptotic value of about $80 \%$ at higher level of substitution.

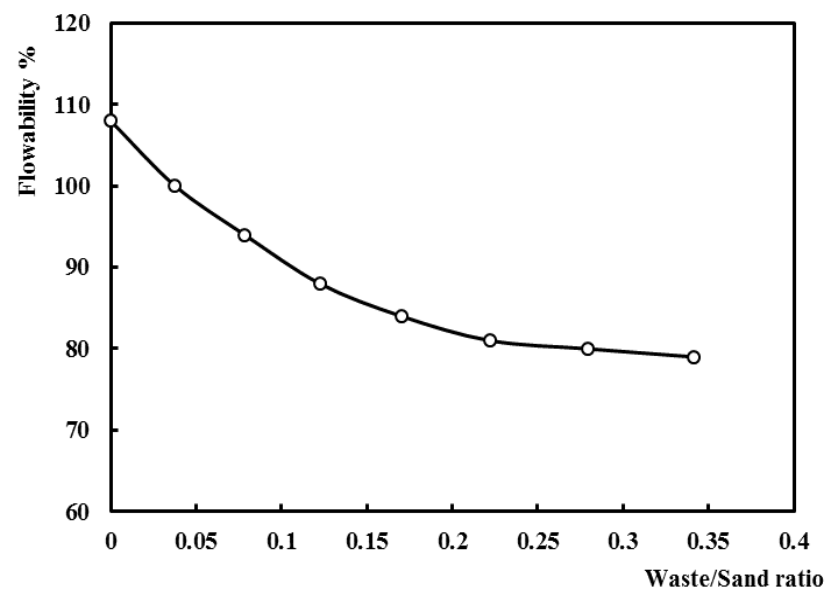

Fig.4. Effect of waste addition on flowability of cement mortar

This result agrees with the findings of Klangvijit et al [25] who substituted part of sand by fired ceramic waste and obtained a lower workability. In the current case, the presence of fine silica in the waste induced some pozzolanic effect that assisted in calcium silicate crystallization which was an additive factor in decreased workability.

Published By:

Blue Eyes Intelligence Engineering \& Sciences Publication 


\section{E. Effect of waste replacement for sand on compressive strength of mortar}

The effect of substituting waste for sand at different levels on 3, 7 and 28 days compressive strength is illustrated in Fig. 5. The curves show a slight increase in strength following addition of waste that practically levels off after 3 and 7 days after a substitution level of waste/sand of 0.28 is reached. The 28 day curve deserves special mentioning as the strength slightly increases from an initial value of about $42.7 \mathrm{MPa}$ to reach a maximum of about $50 \mathrm{MPa}$, a value $17 \%$ higher than the zero waste value at a substitution level of about 0.28 to resume decreasing at higher waste doses. A possible interpretation relates to reaching a maximum packing at that level of addition. Since all the used materials have fairly comparable densities, than their weigh ratios can be considered to be roughly proportional to their volume ratios. Form table 2, at the maximum strength obtained, the masses of materials used were: cement (Fine) $=170$ g., waste (intermediate) $=60$ g., sand $($ coarse $)=215$ g. this gives a volume percentage of about: coarse: intermediate: fine = 48:15:37. According to Norton [26], a maximum packing is achieved with a corresponding ratio of 50: 17: 33. The closeness of the two ratios implies that the maximum strength obtained is essentially due to reaching a maximum packing ratio at that composition.

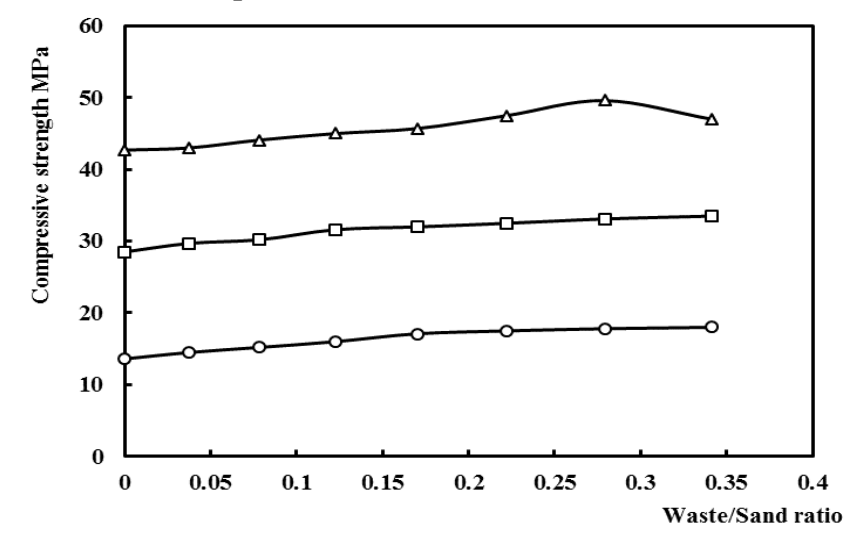

Fig.5. Effect of waste addition on compressive strength of
cement mortar

\section{CONCLUSION}

Porcelain insulators waste chinks were crushed and ground to be substituted for sand in cement mortars as a first step to potentially using this technique in concrete works. Sand was replaced by up to about $34 \%$ of its weight. The following results were obtained: Water of consistency: The substitution of sand by porcelain waste resulted in increasing the water of consistency of cement paste by about $50 \%$ over its initial value.

Setting time: The relatively mild pozzolanic character of the waste assisted in decreasing both initial and final setting times by moderate values.

Flowability: As the addition of an inert ingredient to cement mortar has been previously reported to decrease workability, this was also the case. The mild pozzoloanic activity of the waste helped to slightly accentuate that effect.

Compressive strength: The 28 days compressive strength slightly increased by using waste as substitute for sand to reach a maximum value of about $50 \mathrm{MPa}$ at a waste/sand level of about 0.28 owing to increased packing density.

\section{ACKNOWLEDGMENT}

I am grateful to Prof . M.F. Abadir, Chemical engineering professor, faculty of engineering, Cairo University for his support, guidance and thoughtful encouragement.

\section{REFERENCES}

1. S. Jiemsirilers, S.Jinawath, K. Saiintawong, M.Tada, "Forming Porcelain Insulators" Ceram. Ind. 2008

2. E.M. Ajakor, L.U. Anih, C.M. Ogwata, "Indigenous production of electrical porcelain from Nigerian mineral” Int. J. Sci. Res. Pub. Vol. 5(6), 2015, pp. 1 - 3 .

3. American National Standard for Electrical Power Insulators ANSI/NEMAC29-1, 2018.

4. R.A.P de Oliveira., J.P. Castro-Gomez., P. Santos, "Mechanical and durability properties of concrete with ground waste glass sand" 1DBMC International Conference on Durability of Building Materials and Components Istanbul, Turkey 11-14 May 2008

5. M. Mageswari, B. Vidivelli, "The use of sheet glass powder as fine aggregate replacement in concrete" Open Civ. Eng. J. Vol. 4, 2010, pp. $65-71$

6. S. Keerthinarayana, R. Srinivasan, "Study on strength and durability of concrete by partial replacement of fine aggregate using crushed spent fire bricks" Bull. Int. Polytech. Din Iaşi Vol. 60, 2010, pp. 51 - 63

7. P. Aggarwal, Y. Aggarwal, S.M. Gupta, "Effect of bottom ash as replacement of fine aggregates in concrete", Asian J. Civ. Eng. Vol. 8 (1), 2007, pp. $49-62$

8. V. Aggarwal, S.M. Gupta, S.N. Sachdeva, "Concrete durability through high volume fly ash concrete" Int. J. Eng. Sci. Tech. Vol. 2(9), 2010, 4473 - 4477

9. V.M. Reddy, "Investigations on stone dust and ceramic scrap as aggregate replacement in concrete" Int. J. Civ. Struct. Eng. Vol. 1(3), 2010, pp.661 - 666

10. N.L. Rahim, N.M. Ibrahim, S. Salehuddin, R.C. Amat, S.A. Mohammed, C.R. Hibadullah, "The utilization of aluminum waste as sand replacement in concrete” Key Eng, Mater. Vol. 594, 2014, pp. 455 $-459$

11. J.K. Prusty, S.K. Patro, S.S. Basarkar, "Concrete using agro-waste as fine aggregate for sustainable built environment” Int. J. Sustain. Build. Environ. Vol. 5(2), 2016, pp.312 - 333

12. J. Thorneycroft, J. Orr, P. Savoikar, R.J. Ball, "Performance of structural concrete with recycled plastic waste as a partial replacement for sand" Const. Build. Mater. Vol. 161, 2018, pp. 63 - 69

13. H.E. Bendary, M.F. Abadir, H. Moselhy, H.B.G. Ghazal, "Effect of alum waste addition on the fluidity, initial and finial setting and compressive strength of ordinary Portland cement mortar" Int. J. Chem. Eng. Res. Vol. 9(1), 2017, pp. 89 - 98

14. H. Moselhy, "Effect of dealuminated kaolin waste on slump and compressive strength for ordinary Portland cement concrete" Int. J. Chem. Eng. Res. Vol. 10(2), 2018, pp. 85 - 94

15. ASTM D 422-66 "Standard Test Method for Particle-Size Analysis of Soils", 2007

16. B. D. Cullity, "Elements of X-ray diffraction" $2^{\text {nd }}$ ed. Addison-Wesley, Reading, Mass, (1978).

17. ASTM D854 - 14 "Standard Test Methods for Specific Gravity of Soil Solids by Water Pycnometer, 2014.

18. ASTM C187-16 "Standard Test Method for Amount of Water Required for Normal Consistency of Hydraulic Cement Paste", 2016.

19. ASTM C191-19 "Standard Test Methods for Time of Setting of Hydraulic Cement by Vicat Needle", 2019

20. ASTM C 1437-15 "Standard Test Method for Flow of Hydraulic Cement Mortar", 2015

21. ASTM C230 / C230M - 14 "Standard Specification for Flow Table for Use in Tests of Hydraulic Cement", 2014.

22. ASTM C109 / C109M - 16a "Standard Test Method for Compressive Strength of Hydraulic Cement Mortars", 2016.

23. P. Lawrence, M. Cyr, E. Ringot, "Mineral admixtures in mortars: Effect of inert materials on short-term hydration" Const. Build. Mater.Vol 18, 2003, pp. 1939 - 1947 
24. P. Thongsanitgarn, P. Wongpeo, S. Sinthupynio, A. Chaipanich "Effect of limestone powders on compressive strength and setting time of Portland-limestone cement pastes" TIChE Int. Conf., Hatyai, Songkhla. Thailand, Nov.2011.

25. W. Klangvijit, K. Sookramoon "Study of the mix cement properties of mortar cement used in masonry and plaster from the waste biscuit firing of ceramic" MATEC Web of Conferences 187, 2005

26. F.H. Norton Refractories, 2nd Ed.., McGraw-Hill, New York, 1942.

\section{AUTHOR PROFILE}

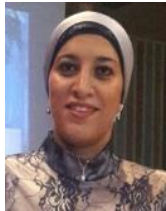

Chemical Engineering Assistant Professor, PhD in chemical engineering (Inorganic industries), Cairo University, Giza, Egypt, under the title of: The Use of Factorial Design in Optimizing the Extraction of Alum from Egyptian Kaolin Clay. E-mail: nourafathy_1983@cu.edu.eg

Research Interests:

Chemical engineering in general specifically in inorganic industries, environmental engineering, renewable energy, water treatment, nuclear energy, environmental engineering and waste managements

\section{Recent publications:}

- F.I. Barakat, N.F. Abdel Salam, Effect of Addition of Polypropylene Fibers on The Properties of Gypsum Blocks, Journal of Advanced Chemical Sciences, Volume 5 Issue 2 (2019) 629-631

- M.F. Abadir, F.I. Barakat, N.F. Abdel Salam, Kinetics of Pyrolysis of Olive Kernels, Journal of Applied Chemistry (IOSR-JAC), Volume 12, Issue 4 Ser. I (April. 2019), 50-56

- S.T. El Sheltawy, N.F. Abdel Salam, F.I. Barakat, Acidic Reaction of Waste Aluminum Foil for Alumina Production, Journal of Environmental Science and Pollution Research, Vol. 5 Issue 1 (2019) 325-327

- E.F. Abadir, N.F. Abdel Salam, F.I. Barakat, Study on production and kinetics of Chitosan from Shrimp Shell Waste Using Factorial Design Experimental Technique, Journal of Advanced Chemical Sciences (JACS), Vol 5, Issue 1, 2019

- S. T. Aly, N. F. Abdel Salam, K. H. Hamad, S.M.S.Abdel-Hamid, Oxidation Kinetics of Tungsten Carbide- 20cobalt Composite using Non-Isothermal Thermal Analysis, International Journal of Engineering Research \& Technology (IJERT), ISSN: 2278-0181, Vol. 7 Issue 11, November-2018

- N.F. Abdel Salam, Review of Ethanol Production from Fruit Wastes, Proceedings of Research World International Conference, Rome, Italy, 25 $-26^{\text {th }}$, June 2018

- El-Shimaa M. El-Zahed, M. F. abadir, F. I. Barakat, N.F. Abdel Salam, Sh.K. Amin, Settling Characteristics of Wastewater from the Ceramic Tile Industry Treated with Different Coagulants, International Journal of Scientific and Engineering Research (IJSER), ISSN 2229-5518, Volume 8, Issue12, December 2017

El-Shimaa M. El-Zahed, Sh.K. Amin, N.F. Abdel Salam, F.I. Barakat, M.F. Abadir, Rheological Properties of Wastewater from the ceramic tile Industry Treated with Different Coagulants, European Journal of Scientific Research, Volume 148 Issue 1, 2017

- S. T. Ghaly, N.F. Abdel Salam, F. I. Barakat, M.F. Abadir, Isothermal kinetics of thermal decomposition of corncobs, International Journal of Scientific Progress and Research (IJSPR), ISSN: 2349-4689, Vol. 37 Issue 1062017 